\title{
Brown carbon absorption linked to organic mass tracers in biomass burning particles
}

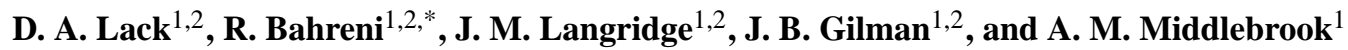 \\ ${ }^{1}$ NOAA Earth System Research Laboratory, Chemical Sciences Division, 325 Broadway, Boulder, CO 80304, USA \\ ${ }^{2}$ Cooperative Institute for Research in Environmental Sciences, University of Colorado, 216 UCB, Boulder, CO 80309, USA \\ *now at: the University of California, Riverside, CA, 92521, USA
}

Correspondence to: D. A. Lack (daniel.lack@noaa.gov)

Received: 9 October 2012 - Published in Atmos. Chem. Phys. Discuss.: 13 November 2012

Revised: 19 February 2013 - Accepted: 20 February 2013 - Published: 1 March 2013

\begin{abstract}
Traditional gas and particle phase chemical markers used to identify the presence of biomass burning (BB) emissions were measured for a large forest fire near Boulder, Colorado. Correlation of the organic matter mass spectroscopic $m / z 60$ with measured particle light absorption properties found no link at $532 \mathrm{~nm}$, and a strong correlation at $404 \mathrm{~nm}$. Non-black carbon absorption at $404 \mathrm{~nm}$ was well correlated to the ratio of the mass fractions of particulate organic matter (POM) that was $m / z 60\left(f_{60}\right)$ to $m / z 44\left(f_{44}\right)$. The $f_{60}$ to $f_{44}$ ratio did not fully explain the variability in non-BC absorption, due to contributions of brown carbon $(\mathrm{BrC})$ absorption and absorption due to internal mixing of POM with black carbon (BC). The absorption Ångstrom exponent $\left(\AA_{\text {Abs }}\right)$ showed a good correlation to $f_{60} / f_{44}$; however the best correlation resulted from the mass absorption efficiency (MAE) of BrC at $404 \mathrm{~nm}$ (MAEPOM-404 nm) and $f_{60} / f_{44}$. This result indicates that the absorption of POM at low visible and UV wavelengths is linked to emissions of organic matter that contribute to the $m / z 60$ mass fragment, although they do not contribute to $532 \mathrm{~nm}$ absorption. $\mathrm{m} / \mathrm{z} 60$ is often attributed to levoglucosan and related compounds. The linear relationship between MAE suggests that the strength of $\mathrm{BrC}$ absorption for this fire can be predicted by emissions of $f_{60}$-related organic matter.
\end{abstract}

\section{Introduction}

The identification of biomass burning (BB) plumes using chemical markers has immense value in identifying sources, transport and processing of emissions (e.g. Roberts et al.,
2011; Stohl et al., 2007; Warneke et al., 2010; Hecobian et al., 2011; Simpson et al., 2011; Andreae, 1983) which can then inform discussions on the potential impacts and mitigation options of BB pollution near sensitive regions for human health or climate (Smith, 1987; Fullerton and Bruce, 2008; Innes et al., 2000; Ramanathan and Carmichael, 2008). The effectiveness of a chemical marker is related to its atmospheric reactivity and specificity to the BB source (Aiken et al., 2010; Andreae, 1983; Hennigan et al., 2010; Simoneit et al., 1999). Carbon monoxide (CO), acetonitrile, hydrogen cyanide, potassium and levoglucosan for example help to distinguish BB plumes from other sources in the gas and particle phase (de Gouw et al., 2003; Simoneit et al., 1999; Andreae, 1983).

Levoglucosan is a common BB particle tracer (Simoneit et al., 1999). It is an organic molecule formed from the pyrolysis of cellulose and can dimerize or polymerize to form a family of combustion-linked particulate organic matter (POM) having a characteristic mass fragment at $m / z 60$ $\left(\mathrm{C}_{2} \mathrm{H}_{4} \mathrm{O}_{2}^{+}\right)$upon electron impact ionization. The fraction of $m / z 60\left(f_{60}\right)$, compared to the fraction of the "oxidized organic" mass fragment $m / z 44\left(\mathrm{CO}_{2}^{+}\right)\left(f_{44}\right)$ provides a unique picture of BB POM aging and mixing (Cubison et al., 2011; Innes et al., 2000). $f_{44}$ in a BB plume will increase, and $f_{60}$ decrease, as the levoglucosan-based compounds oxidize (Adler et al., 2011; Cubison et al., 2011) while $f_{60}$, which has a small non-BB background, will increase as the absolute amount of BB increases (Aiken et al., 2008; Alfarra et al., 2007; Cubison et al., 2011).

The climate impacts of $\mathrm{BB}$ emissions are determined by the optical properties of the emitted particles, which contain 
mostly POM, black carbon (BC) and some inorganic material (Lack et al., 2012b; Kondo et al., 2011; Posfai et al., 2003, 2004). These components contribute to light scattering and, critically, to wavelength dependent absorption by BC, absorption enhancement through internal mixing of $\mathrm{BC}$ and POM, and absorption by POM itself (i.e. brown carbon or BrC) (Lack and Cappa, 2010; Lack et al., 2012b; Kirchstetter et al., 2004; Reid et al., 2005). Here we investigate the relationships between the aerosol mass spectrometer (AMS) measured POM chemical markers $(\mathrm{m} / \mathrm{z} 60, \mathrm{~m} / \mathrm{z} 44)$ and these optical properties. We confirm the traditional links between the BB gas phase and particle phase chemical markers (Sect. 3.1) while in Sect. 3.2 we compare BB particle optical properties to the ratio of $f_{60}$ to $f_{44}$ as a link to the $f_{60}$ and $f_{44}$ relationship for BB particles detailed in Cubison et al. (2011). In Sect. 3.3 we present the BrC optical property link to the absolute mass of $m / z 60$.

\section{Experimental}

\subsection{Instrumentation}

Experimental details for these measurements can be found in Lack et al. (2012b). Briefly, the measurements reported here were taken $24 \mathrm{~h}$ after ignition of a large Ponderosa Pine forest fire near Boulder, Colorado. The fire occurred during hot, dry conditions, destroyed 168 houses and, during the sampling period, consisted of both flaming and smoldering ponderosa pine, grasses and likely smaller contributions of burning structures. A photo-acoustic aerosol absorption spectrometer (PAS) measured dry total absorption at $658 \mathrm{~nm}, 532 \mathrm{~nm}$ and $404 \mathrm{~nm}\left(b_{\text {Abs-658 }}, b_{\text {Abs-532 }}, b_{\text {Abs-404 }}\right)$ and thermal-denuded absorption (sample heated to $200^{\circ} \mathrm{C}$ ) at $532 \mathrm{~nm}$ and $404 \mathrm{~nm}$ ( $b_{\text {Abs-532-BC }}, b_{\text {Abs-404-BC }}$ ) (Lack et al., 2012a). The PAS system has $50 \%$ size cut at approximately $4 \mu \mathrm{m}$. Total nonrefractory particle mass (POM and ammonium nitrate) was measured using an compact time-of-flight aerosol mass spectrometer (AMS, Bahreini et al., 2009). Collection efficiency was calculated using the composition-dependent parameterization as outlined in Middlebrook et al. (2011). For the signal levels measured and time resolution reported, measurement uncertainties are estimated as follows; AMS $- \pm 38 \%$, PAS $532 \mathrm{~nm}$ and $658 \mathrm{~nm}- \pm 5 \%$, PAS $404 \mathrm{~nm}- \pm 10 \%$. From these measurements the following absorption-related properties were calculated; absorption enhancements at $532 \mathrm{~nm}$ and $404 \mathrm{~nm}\left(E_{\mathrm{Abs}-532}, E_{\mathrm{Abs}-404}\right)$ using Eqs. (1) and (2); absorption Ångstrom exponent ( $\left.\AA_{\text {Abs }}\right)$ using Eq. (3); and mass absorption efficiency of POM at $404 \mathrm{~nm}$ using Eq. (4):

$$
\begin{aligned}
& E_{\text {Abs-532 }}=\frac{b_{\text {Abs-532 }}}{b_{\text {Abs-532-BC }}} \\
& E_{\text {Abs-404 }}=\frac{b_{\text {Abs- } 404}}{b_{\text {Abs- } 404-\mathrm{BC}}}
\end{aligned}
$$

$\AA_{\mathrm{Abs}}=\frac{\ln \left(\frac{b_{\mathrm{Abs}}\left(\gamma_{1}\right)}{b_{\mathrm{Abs}}\left(\gamma_{2}\right)}\right)}{\ln \left(\frac{\gamma_{1}}{\gamma_{2}}\right)}$

$\mathrm{MAE}=\frac{b_{\text {Abs-404-POM }}}{m_{\mathrm{POM}}}$

The absorption term $b_{\text {Abs-404-POM }}$ is a combination of measured and modeled data from Lack et al. (2012b) and consists of $b_{\mathrm{Abs}-404}-b_{\mathrm{Abs}-404-\mathrm{BC}}$ with an additional absorption term for internal mixing removed via Mie Theory. $m_{\mathrm{POM}}$ does not include ammonium nitrate mass.

The BB plume sampled was the same from the study of Lack et al. (2012b). Within this work, there were distinctly different periods of emissions that were classified according to the apparent influence of BB. Some figures in this work are clarified using these data periods. Two periods were almost devoid of BB influence (colored black and yellow in all but Fig. 1) while there were two periods heavily influenced by BB emissions (colored brown and orange in all but Fig. 1) that were found to differ in their $404 \mathrm{~nm}$ optical properties by an additional absorption contribution from internal mixing. Lack et al. (2012b) removed this additional absorption term using a modeling step to produce a MAE for $\mathrm{BrC}$ at $404 \mathrm{~nm}$, which is used in this study.

An in-situ, dual channel, gas chromatograph - mass spectrometer (GC-MS) measured acetonitrile (and propene, 1,3-butadiene, and benzene used in the Supplement). Two $350 \mathrm{~mL}$ gas-phase samples were simultaneously collected via cryogenic trapping. The samples were then analyzed using an $\mathrm{Al}_{2} \mathrm{O}_{3}$ porous layer open tubular column (Channel 1) or a DB-624 capillary column (Channel 2) coupled to a quadrupole mass spectrometer (Roberts et al., 2011). The entire sample acquisition ( $5 \mathrm{~min}$ ) and analysis ( $25 \mathrm{~min}$ ) scheme repeated every $30 \mathrm{~min}$. Measurement precision is $\pm 5 \%$ and accuracy is $\pm 20 \%$. Carbon Monoxide (CO) was measured using a UV fluorescence method (AeroLaser Model AL5002) (Williams et al., 2009).

\subsection{AMS mass factorization}

While $m / z 60$ is a common fragment found in the mass spectra of BB particles, many other mass fragments e.g., $m / z 73$, $\mathrm{m} / \mathrm{z} 30$ and $\mathrm{m} / \mathrm{z} 64$, may also be contribute to the spectra (Aiken et al., 2010; Alfarra et al., 2007; Cubison et al., 2011; Lanz et al., 2010). Positive-matrix-factorization (PMF), a method that identifies different organic aerosol (OA) factors representing different sources or atmospheric processes (Ulbrich et al., 2009), has been used in several studies to determine a more detailed biomass-burning organic aerosol (BBOA) factor (Aiken et al., 2008; Lanz et al., 2010). The BBOA factor has a strong ion signature of levoglucosan from BB at $m / z 60$ and correlates well with gas phase biomass markers such as $\mathrm{HCN}$ and acetonitrile as well as $\mathrm{CO}$ (Aiken et al., 2010; Lanz et al., 2010). The $m / z 44$ mass fragment, 


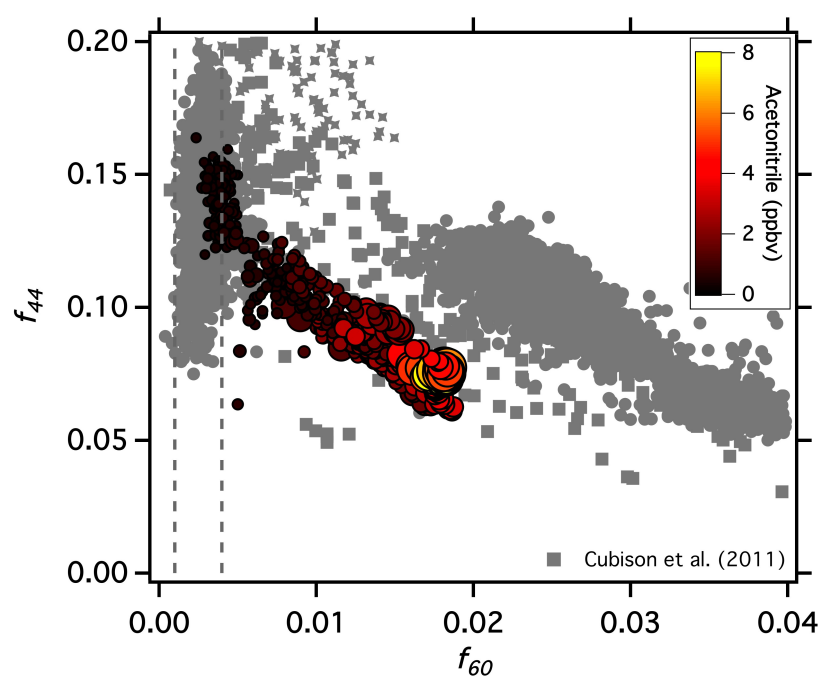

Fig. 1. Relationship between AMS $f_{44}$ and $f_{60}$, colored by acetonitrile and sized by $\mathrm{CO}$ concentration. Range of background $f_{60}$ levels shown as the vertical dashed lines (Cubison et al., 2011). Grey data is all data from Cubison et al. (2011). Acetonitrile determined from interpolation of the discrete GC-MS samples.

often assigned to an oxidized organic factor (OOA), is typically enhanced in the BBOA factor as well. The BBOA factor may also have a hydrocarbon signature similar to the less oxidized organic factor (HOA), making complete separation of BBOA and HOA challenging with PMF (He et al., 2011). In this study we were not able to adequately resolve the BBOA, OOA, and HOA factors using the traditional PMF methods. An alternative factorization analysis (ME-2, Lanz et al., 2007) may better resolve these factors. Investigation of the relationships between the optical properties and refined BBOA factors is beyond the scope of this paper, although should be the focus of future studies as BBOA mass is likely to be a more accessible metric in climate models than $\mathrm{m} / \mathrm{z}$ 60 , or $m / z 44$.

\section{Results}

\subsection{Traditional markers}

The traditional gas-phase markers of acetonitrile and carbon monoxide (CO) show the largest enhancements during periods of elevated $f_{60}$. This indicates that $\mathrm{BB}$ gas phase markers are directly linked to the levoglucosan-based particle phase species which shows consistent identification of a BB influenced air mass (Fig. 1). The $f_{44}$ and $f_{60}$ relationship is also consistent with Cubison et al. (2011) on aging phenomenon of POM in BB particles and/or mixing with more oxidized POM (Fig. 1). The data presented here perhaps contains a lower overall contribution of $f_{44}$ than observed by Cubison et al. (2011). One period of sampling shows an average $f_{60}$ of 0.0042, which is described by Cubison et al. (2011) as an upper limit to the background level of $f_{60}$, and indicates very little BB influence (shown as the black data in Figs. 2 and 3). Although the relationship between $f_{44}$ and $f_{60}$ in Fig. 1 cannot explicitly separate aging or mixing, the relationship between reactive VOC markers for BB (e.g., benzene, propene, and 1,3-butadiene) and acetonitrile indicate that the two biomass burning plumes were of similar photochemical ages (see Supplement and Fig. S1). Physical plume ages were likely between 1-12 h, however high resolution back trajectory analysis is not available to provide a better estimate. For reference, the emissions ratios of POM to $\mathrm{CO}$ are presented in the Supplement Fig. S4.

\subsection{Optical properties and AMS $f_{60}, f_{44}$}

\subsubsection{Absorption enhancement $\left(E_{\mathrm{Abs}}\right)$}

$E_{\mathrm{Abs}}$ is the amount of absorption that is due to non-BC material through radiation lensing of coatings on $\mathrm{BC}$ cores and/or absorption by $\mathrm{BrC}$. At $404 \mathrm{~nm} E_{\mathrm{Abs}}$ increases as $f_{60}$ increases, although the relationships are dependent of the period of sampling (Fig. 2a). The two periods of elevated $E_{\text {Abs-404 }}$ observed in Fig. 2a (brown and orange data) diverge at elevated levels of $f_{60}$. These periods correspond to the heavily BB influenced periods identified in Lack et al. (2012b). The black and yellow data correspond to background air masses with little or no BB influence. These data periods were separated based on the observed levels of PM mass, and absorption enhancements (Lack et al., 2012b). The difference in $E_{\text {Abs-404 }}$ between these periods was shown to be due to the influence of internal mixing of non-absorbing POM with BC, possibly from anthropogenic sources or secondary production of POM (Hennigan et al., 2011; Grieshop et al., 2009). The brown and orange data show robust and statistically significant linear correlations (brown data: slope $=9.2 \pm 0.2, R^{2}=0.93$; orange data: slope $=5.6 \pm 0.2, R^{2}=$ $0.95)$. Therefore $f_{60} / f_{44}$ does not fully explain the behavior of $E_{\mathrm{Abs}-404}$. In addition, there is no evidence of a relationship between $E_{\mathrm{Abs}-532}$ and $f_{60} / f_{44}$ (Fig. $2 \mathrm{~b}$ ), which indicates there is very little (if any) contribution of $f_{60}$ to $532 \mathrm{~nm}$ absorption.

\subsubsection{Absorption Ångstrom exponent $\left(\AA_{\text {Abs }}\right)$}

Absorption Ångstrom exponent is often interrogated for indications of $\mathrm{BB}$ influenced particles, where it is assumed that an $\AA_{\mathrm{Abs}}>1$ is indicative of absorption by more than just BC, such as dust and $\mathrm{BrC}$ (Gyawali et al., 2009; Lewis et al., 2008; Corr et al., 2012; Yang et al., 2009; Favez et al., 2009). There is a correlation between wavelength dependency of absorption for this heavily BB influenced plume $\left(\AA_{\mathrm{Abs}}\right)$ and $f_{60} / f_{44}$ (Fig. 3). This is strong evidence that the $\AA_{\mathrm{Abs}}$ and absorption at $404 \mathrm{~nm}$ for BB emissions is directly correlated to the levoglucosan-based products of BB combustion, although there may be some contribution from secondary 

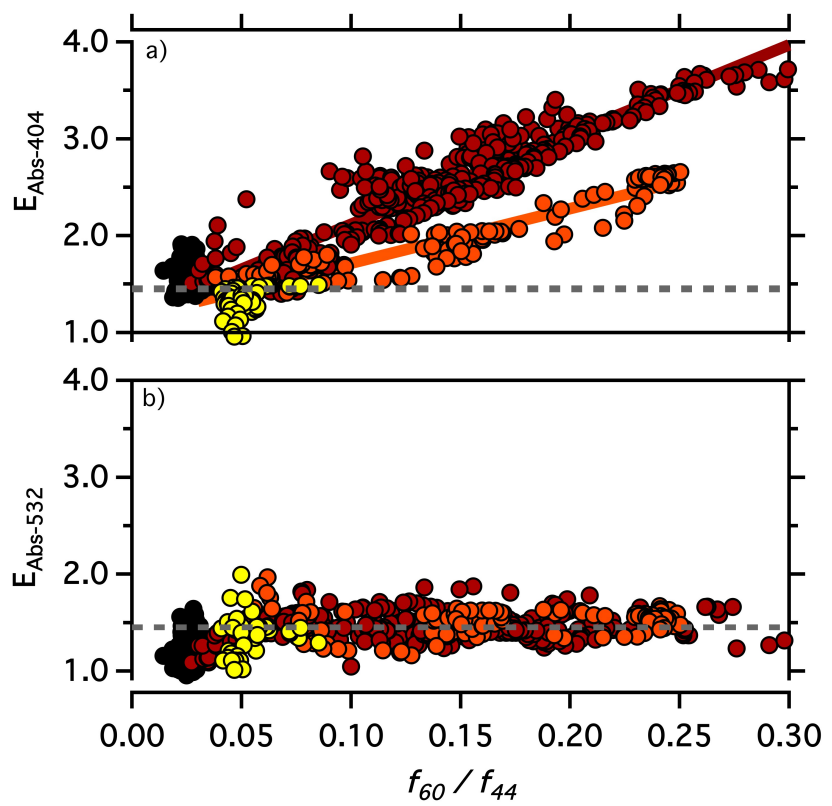

Fig. 2. Absorption enhancement relationship with $f_{60} / f_{44}$ at (a) $404 \mathrm{~nm}$ and (b) $532 \mathrm{~nm}$. The color-coding shows the different sampling periods of the BB plume. Horizontal dashed line indicates reasonable $E_{\mathrm{Abs}}(1.5)$ expected from theory from internal mixing only (Bond et al., 2006). Linear fits for red and orange data periods shown in (a). (red data: slope $=9.2 \pm 0.2, R^{2}=0.93$; orange data: slope $\left.=5.6 \pm 0.2, R^{2}=0.95\right)$.

functional groups that actually absorb light. There is some scatter and apparent curvature in this relationship however, particularly between the three sampling periods, which may be due to the influence of particle size or coating effects on the $\AA_{\text {Abs }}$ (Lack and Cappa, 2010; Moosmuller et al., 2011). Although it appears that a linear relationship is not valid for this dataset, we performed a linear regression on this data to provide some quantification of the relationship, to compare to other relationships in Sect. 3.2. The slope and $\mathrm{R}^{2}$ for the brown data are $11.4 \pm 0.4$ and 0.85 respectively while the slope and $R^{2}$ for the orange data are $9.1 \pm 0.4$ and 0.8 respectively. These correlations are almost 3 standard deviations apart, with relatively low correlation coefficients, compared to the other relationships presented.

\subsubsection{Mass absorption efficiency (MAE) of brown carbon}

Of the optical parameters investigated, the MAE of the POM at $404 \mathrm{~nm}$ (MAE ${ }_{\mathrm{POM}-404 \mathrm{~nm}}$ ), shows the most robust relationship with $f_{60} / f_{44}$ (Fig. 4). Both periods of data (brown and orange) show the same slope (within 1 standard deviation of the mean). The brown data has a slope of $6.8 \pm 0.1$ $\left(R^{2}=0.93\right)$ while the orange data has a slope of $7.0 \pm 0.1$ $\left(R^{2}=0.93\right)$. The ratio of $f_{60} / f_{44}$ appears to be a good proxy for just $\mathrm{BrC}$ absorption for this fire. The MAE reported does

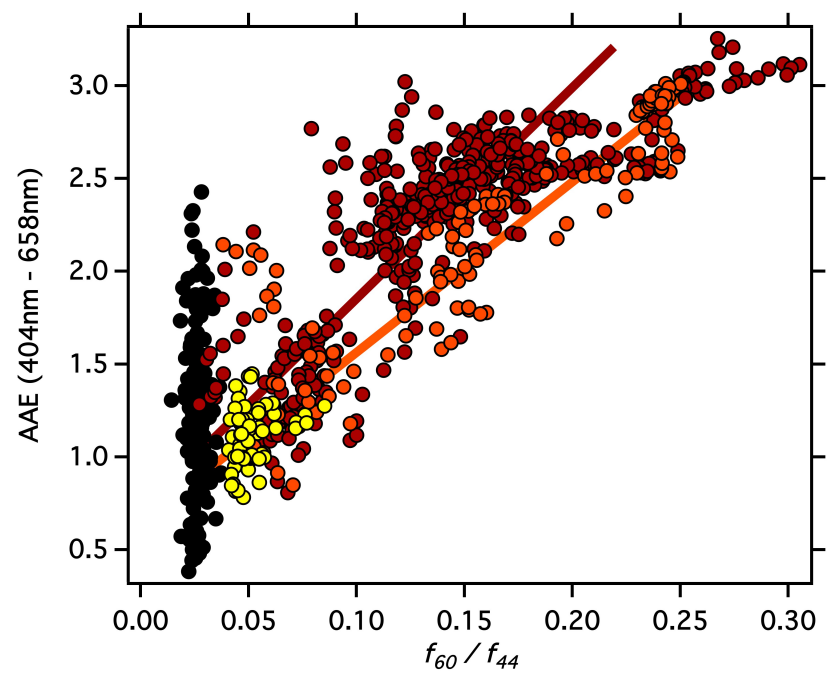

Fig. 3. Absorption Ångstrom Exponent $\left(\AA_{\text {Abs }}\right)$ versus $f_{60} / f_{44}$. The color-coding shows the BB plumes sampled (Lack et al., 2012b). Linear fits for red and orange data periods also shown as solid lines (red data: Slope $=11.4 \pm 0.4, R^{2}=0.85$, orange data: slope $=$ $\left.9.1 \pm 0.4, R^{2}=0.8\right)$.

not contain any absorption contribution from internal mixing (removed via a modeling step, Lack et al., 2012b) and the subsequent relationship does not show any differentiation between the two different emissions periods observed in the $E_{\text {Abs-404 }}$ (Fig. 2a). This indicates that the $f_{60}-$ linked combustion products do not have an influence on the absorption created through internal mixing (a result also shown in Fig. $2 b$ ) but does provide a robust link to $\mathrm{BrC}$ absorption. The emissions sampled here were close to the emissions source, and gas phase markers indicate that there was minimal atmospheric processing (shown in the Supplement). The large range in $f_{60}$ and $f_{44}$ therefore indicates extensive mixing of air masses with minimal atmospheric processing. Therefore, the observed link between MAE and $f_{60} / f_{44}$ shows that the strength of $\mathrm{BrC}$ absorption is linked to the emissions of the $f_{60}$-related organics, and ranges from $0.25 \mathrm{~m}^{2} \mathrm{~g}^{-1}$ to $1.5 \mathrm{~m}^{2} \mathrm{~g}^{-1}$ (which compares well to measurements from other studies $-0.5 \mathrm{~m}^{2} \mathrm{~g}^{-1}$ to $2.9 \mathrm{~m}^{2} \mathrm{~g}^{-1}$, Hoffer et al., 2006; Yang et al., 2009; Kirchstetter et al., 2004). Some studies show low-visible and UV absorption of POM from BB being linked to nitrated levoglucosan-based compounds (Claeys et al., 2012; Kitanovski et al., 2012). Our data cannot differentiate between inorganic and organic nitrates, however these compounds remain a possibility as the contributors to $\mathrm{BrC}$ absorption. Other studies show BrC absorption efficiency increasing as it is oxidized (Corr et al., 2012; Marley et al., 2009; Adler et al., 2011; Bones et al., 2010), presumably from processing of emitted POM or secondary POM formed from VOC emissions, to produce low-visible and UV-active chromophores. Our data does not provide an opportunity to 


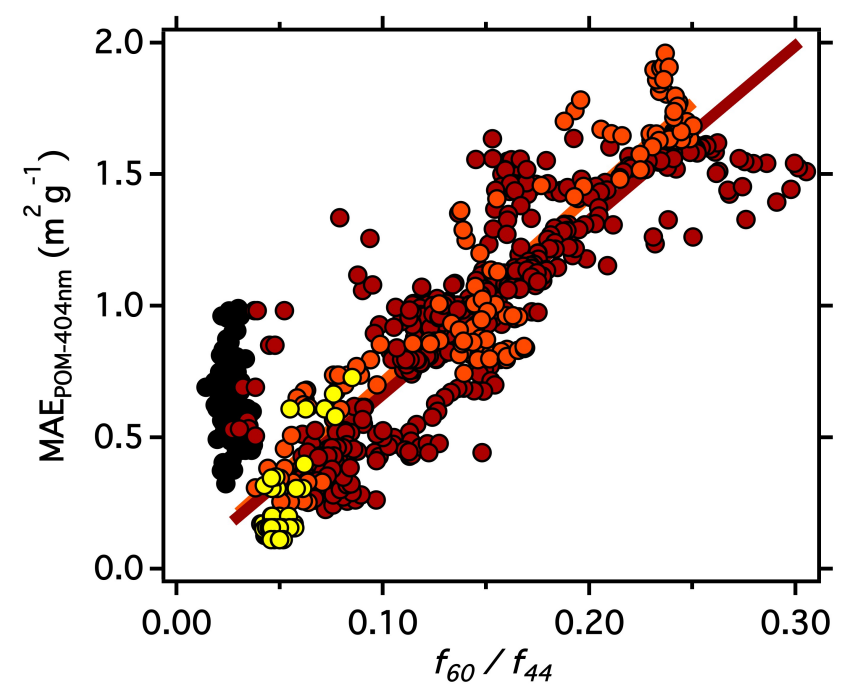

Fig. 4. Mass absorption efficiency (MAE, at $404 \mathrm{~nm}$ ) versus $f_{60} / f_{44}$. The color-coding shows the BB plumes sampled (Lack et al., 2012b). Linear fits for red and orange data periods also shown as solid lines (red data: Slope $=6.8 \pm 0.1, R^{2}=0.93$, orange data: slope $\left.=7.0 \pm 0.1, R^{2}=0.93\right)$.

asses this link between atmospheric processing of $f_{60}$ related organics and BrC optics.

\subsubsection{Brown carbon mass absorption efficiency and the absolute mass of $m / z 60$}

Correlations between MAE and the absolute mass of organic material likely provide a more accessible link between optical and chemical properties. Figure 5 shows that for the intense biomass burning periods (red and brown data) there is a robust linear correlation between MAE and $\log (m / z, 60$ mass $\left(R^{2}\right.$ of 0.88$)$. This relationship to absolute mass is fundamentally different than the others and indicates that $\mathrm{BrC}$ absorption strength is not dictated by absolute mass of $\mathrm{m} / \mathrm{z} 60$ and that the contribution from $\mathrm{m} / \mathrm{z} 60$ and $\mathrm{m} / \mathrm{z} 44$ provides a simpler pathway to understanding $\mathrm{BrC}$ absorption. We caution that these relationships are established for this fire only, and for periods identified, using the $f_{44}$ to $f_{60}$ relationship (Fig. 1), as being heavily influenced by biomass-burning.

\section{Conclusions}

The expected link between gas and particle phase chemical markers for biomass burning emissions was observed for a forest fire near Boulder, Colorado. The absorption of $\mathrm{BrC}$ in the particle emissions of this fire is correlated to the mass ratio of the fragments at $\mathrm{m} / z 60$ and $\mathrm{m} / z 44$. The $m / z \quad 60$ fragment is sourced from levoglucosan and levoglucosan-based organics; products of incomplete combustion of cellulose. Measurements of the enhanced absorption due to internal mixing of $\mathrm{POM}$ and $\mathrm{BC}$ and $\mathrm{BrC}$ show

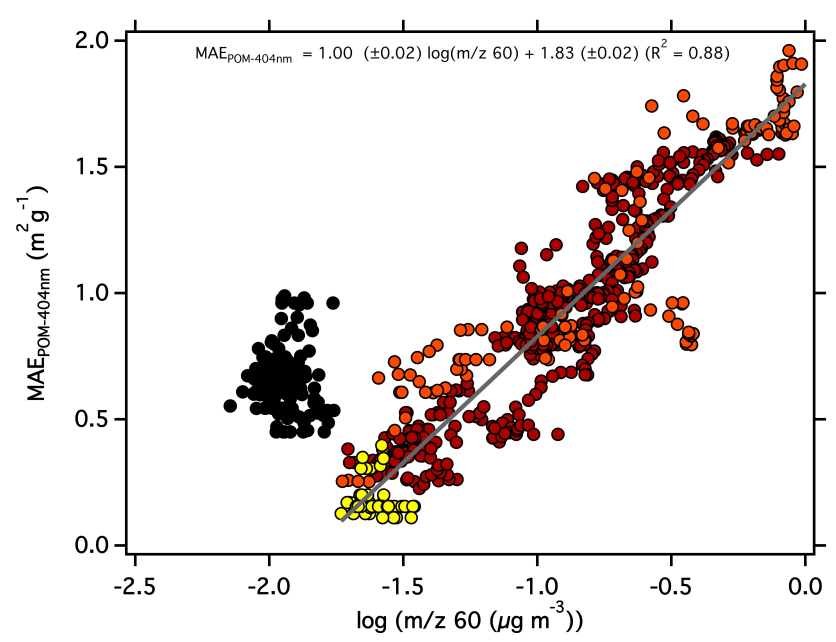

Fig. 5. Mass absorption efficiency (MAE, at $404 \mathrm{~nm}$ ) versus mass of $m / z 60$. The color-coding shows the BB plumes sampled (Lack et al., 2012b). Linear fit to both red and orange data periods also shown as solid lines.

a strong link to the $m / z, 60$ fragment, however divergence of $E_{\mathrm{Abs}-404}$ for two sampling periods heavily influenced by $\mathrm{BB}$ emissions indicate that there are additional contributors to non-BC absorption at $404 \mathrm{~nm}$ (other than chromophores within levoglucosan-based organics). A somewhat scattered relationship between wavelength dependence to absorption ( $\left.\AA_{\text {Abs }}\right)$ and $f_{60} / f_{44}$ indicate that the $404 \mathrm{~nm}$ absorption is linked to chromophores within levoglucosan-based organics. The most robust linear relationship was found between the mass absorption efficiency of the organic matter at $404 \mathrm{~nm}$ (MAE ${ }_{\text {POM- }} 404 \mathrm{~nm}$ ) and $f_{60} / f_{44}$. Given that the photochemical age of the sample plume did not vary, this link does not contain any contributions from atmospheric processing. A linear correlation was also shown between MAE $(m / z 60)$. Future work will need to assess these relationships for different fires, the relationships with the more detailed AMS factorization products such as BBOA, and show how the $\mathrm{BrC}$ absorption is related to atmospheric processing. The observed relationships presented here provide valuable correlations for comparisons to future studies and may provide a pathway to predicting the contribution of $\mathrm{BrC}$ absorption from biomass burning emissions using the chemical composition of the organic particles produced from biomass combustion.

\section{Supplementary material related to this article is available online at: http://www.atmos-chem-phys.net/13/ 2415/2013/acp-13-2415-2013-supplement.pdf.}

Acknowledgements. Funded by NOAAs climate program. Thanks to Brian Lerner for providing the $\mathrm{CO}$ data.

Edited by: M. Petters 


\section{References}

Adler, G., Flores, J. M., Abo Riziq, A., Borrmann, S., and Rudich, Y.: Chemical, physical, and optical evolution of biomass burning aerosols: a case study, Atmos. Chem. Phys., 11, 1491-1503, doi:10.5194/acp-11-1491-2011, 2011.

Aiken, A. C., de Foy, B., Wiedinmyer, C., DeCarlo, P. F., Ulbrich, I. M., Wehrli, M. N., Szidat, S., Prevot, A. S. H., Noda, J., Wacker, L., Volkamer, R., Fortner, E., Wang, J., Laskin, A., Shutthanandan, V., Zheng, J., Zhang, R., Paredes-Miranda, G., Arnott, W. P., Molina, L. T., Sosa, G., Querol, X., and Jimenez, J. L.: Mexico city aerosol analysis during MILAGRO using high resolution aerosol mass spectrometry at the urban supersite (T0) Part 2: Analysis of the biomass burning contribution and the non-fossil carbon fraction, Atmos. Chem. Phys., 10, 5315-5341, doi:10.5194/acp-10-5315-2010, 2010.

Alfarra, M. R., Prevot, A. S. H., Szidat, S., Sandradewi, J., Weimer, S., Lanz, V. A., Schreiber, D., Mohr, M., and Baltensperger, U.: Identification of the mass spectral signature of organic aerosols from wood burning emissions, Environ. Sci. Technol., 41, 57705777, 2007.

Andreae, M. O.: Soot Carbon and Excess Fine Potassium: LongRange Transport of Combustion-Derived Aerosols, Science, 220, 1148-1151, doi:10.1126/science.220.4602.1148, 1983.

Atkinson, R.: Kinetics and mechanisms of the gas-phase reactions of the hydroxyl radical with organic-compounds under atmospheric conditions, Chem. Rev., 86, 69-201, doi:10.1021/cr00071a004, 1986.

Bahreini, R., Ervens, B., Middlebrook, A. M., Warneke, C., de Gouw, J. A., DeCarlo, P. F., Jimenez, J. L., Brock, C. A., Neuman, J. A., Ryerson, T. B., Stark, H., Atlas, E., Brioude, J., Fried, A., Holloway, J. S., Peischl, J., Richter, D., Walega, J., Weibring, P., Wollny, A. G., and Fehsenfeld, F. C.: Organic aerosol formation in urban and industrial plumes near Houston and Dallas, Texas, J. Geophys. Res., 114, D00F16, doi:10.1029/2008jd011493, 2009.

Bond, T., Habib, G., and Bergstrom, R. W.: Limitations in the Enhancement of Visible Light Absorption Due to Mixing State, J. Geophys. Res., 111, D20211, doi:10.1029/2006JD007315, 2006.

Bones, D. L., Henricksen, D. K., Mang, S. A., Gonsior, M., Bateman, A. P., Nguyen, T. B., Cooper, W. J., and Nizkorodov, S. A.: Appearance of strong absorbers and fluorophores in limonene$\mathrm{O}_{3}$ secondary organic aerosol due to $\mathrm{NH} 4+-$-mediated chemical aging over long time scales, J. Geophys. Res., 115, D05203, doi:10.1029/2009jd012864, 2010.

Claeys, M., Vermeylen, R., Yasmeen, F., Gómez-González, Y., Chi, X., Maenhaut, W., Mészáros, T., and Salma, I.: Chemical characterisation of humic-like substances from urban, rural and tropical biomass burning environments using liquid chromatography with UV/vis photodiode array detection and electrospray ionisation mass spectrometry, Environmental Chemistry, 9, 273-284, doi:10.1071/EN11163, 2012.

Corr, C. A., Hall, S. R., Ullmann, K., Anderson, B. E., Beyersdorf, A. J., Thornhill, K. L., Cubison, M. J., Jimenez, J. L., Wisthaler, A., and Dibb, J. E.: Spectral absorption of biomass burning aerosol determined from retrieved single scattering albedo during ARCTAS, Atmos. Chem. Phys., 12, 10505-10518, doi:10.5194/acp-12-10505-2012, 2012.

Cubison, M. J., Ortega, A. M., Hayes, P. L., Farmer, D. K., Day, D., Lechner, M. J., Brune, W. H., Apel, E., Diskin, G. S., Fisher,
J. A., Fuelberg, H. E., Hecobian, A., Knapp, D. J., Mikoviny, T., Riemer, D., Sachse, G. W., Sessions, W., Weber, R. J., Weinheimer, A. J., Wisthaler, A., and Jimenez, J. L.: Effects of aging on organic aerosol from open biomass burning smoke in aircraft and laboratory studies, Atmos. Chem. Phys., 11, 12049-12064, doi:10.5194/acp-11-12049-2011, 2011.

de Gouw, J. A., Warneke, C., Parrish, D. D., Holloway, J. S., Trainer, M., and Fehsenfeld, F. C.: Emission sources and ocean uptake of acetonitrile $(\mathrm{CH} 3 \mathrm{CN})$ in the atmosphere, J. Geophys. Res., 108, 4329, doi:10.1029/2002jd002897, 2003.

Favez, O., Alfaro, S. C., Sciare, J., Cachier, H., and Abdelwahab, M. M.: Ambient measurements of light-absorption by agricultural waste burning organic aerosols, J. Aerosol Sci., 40, 613620, 2009.

Fullerton, D. G. and Bruce, N.: Indoor air pollution from biomass fuel smoke is a major health concern in the developing world, Trans. Roy. Soc. Trop. Med. H., 102, 841-952, 2008.

Grieshop, A. P., Donahue, N. M., and Robinson, A. L.: Laboratory investigation of photochemical oxidation of organic aerosol from wood fires 2: analysis of aerosol mass spectrometer data, Atmos. Chem. Phys., 9, 2227-2240, doi:10.5194/acp-9-2227-2009, 2009.

Gyawali, M., Arnott, W. P., Lewis, K., and Moosmüller, H.: In situ aerosol optics in Reno, NV, USA during and after the summer 2008 California wildfires and the influence of absorbing and non-absorbing organic coatings on spectral light absorption, Atmos. Chem. Phys., 9, 8007-8015, doi:10.5194/acp-9-8007-2009, 2009.

He, L. Y., Huang, X. F., Xue, L., Hu, M., Lin, Y., Zheng, J., Zhang, R., and Zhang, Y. H.: Submicron aerosol analysis and organic source apportionment in an urban atmosphere in Pearl River Delta of China using high resolution aerosol mass spectrometry, J. Geophys. Res., 116, D12304, doi:10.1029/2010JD014566, 2011.

Hecobian, A., Liu, Z., Hennigan, C. J., Huey, L. G., Jimenez, J. L., Cubison, M. J., Vay, S., Diskin, G. S., Sachse, G. W., Wisthaler, A., Mikoviny, T., Weinheimer, A. J., Liao, J., Knapp, D. J., Wennberg, P. O., Kürten, A., Crounse, J. D., Clair, J. St., Wang, Y., and Weber, R. J.: Comparison of chemical characteristics of 495 biomass burning plumes intercepted by the NASA DC-8 aircraft during the ARCTAS/CARB-2008 field campaign, Atmos. Chem. Phys., 11, 13325-13337, doi:10.5194/acp-1113325-2011, 2011.

Hennigan, C. J., Sullivan, A. P., Collett, J. L., Jr., and Robinson, A. L.: Levoglucosan stability in biomass burning particles exposed to hydroxyl radicals, Geophys. Res. Lett., 37, L09806, doi:10.1029/2010g1043088, 2010.

Hennigan, C. J., Miracolo, M. A., Engelhart, G. J., May, A. A., Presto, A. A., Lee, T., Sullivan, A. P., McMeeking, G. R., Coe, H., Wold, C. E., Hao, W.-M., Gilman, J. B., Kuster, W. C., de Gouw, J., Schichtel, B. A., J. L. Collett Jr., Kreidenweis, S. M., and Robinson, A. L.: Chemical and physical transformations of organic aerosol from the photo-oxidation of open biomass burning emissions in an environmental chamber, Atmos. Chem. Phys., 11, 7669-7686, doi:10.5194/acp-11-7669-2011, 2011.

Hoffer, A., Gelencsér, A., Guyon, P., Kiss, G., Schmid, O., Frank, G. P., Artaxo, P., and Andreae, M. O.: Optical properties of humic-like substances (HULIS) in biomass-burning aerosols, Atmos. Chem. Phys., 6, 3563-3570, doi:10.5194/acp-6-3563-2006, 
2006.

Innes, J. L., Beniston, M., and Vertraete, M. M.: Biomass Burning and Climate: An Introduction Biomass Burning and its InterRelationships with the Climate System, edited by: Innes, J. L., Beniston, M., and Verstraete, M. M., Advances in Global Change Research, Kluwer Academic Publishers, New York, 1-13, 2000.

Kirchstetter, T. W., Novakov, T., and Hobbs, P. V.: Evidence That the Spectral Dependence of Light Absorption by Aerosols is Affected by Organic Carbon, J. Geophys. Res., 109, D21208, doi:10.1029/2004JD004999, 2004.

Kitanovski, Z., Grgifá, I., Vermeylen, R., Claeys, M., and Maenhaut, W.: Liquid chromatography tandem mass spectrometry method for characterization of monoaromatic nitro-compounds in atmospheric particulate matter, J. Chromatography A, 1268, 35-43, doi:10.1016/j.chroma.2012.10.021, 2012.

Kondo, Y., Matsui, H., Moteki, N., Sahu, L., Takegawa, N., Kajino, M., Zhao, Y., Cubison, M. J., Jimenez, J. L., Vay, S., Diskin, G. S., Anderson, B., Wisthaler, A., Mikoviny, T., Fuelberg, H. E., Blake, D. R., Huey, G., Weinheimer, A. J., Knapp, D. J., and Brune, W. H.: Emissions of black carbon, organic, and inorganic aerosols from biomass burning in North America and Asia in 2008, J. Geophys. Res., 116, D08204, doi:10.1029/2010jd015152, 2011.

Lack, D. A. and Cappa, C. D.: Impact of brown and clear carbon on light absorption enhancement, single scatter albedo and absorption wavelength dependence of black carbon, Atmos. Chem. Phys., 10, 4207-4220, doi:10.5194/acp-10-4207-2010, 2010.

Lack, D., Langridge, J., Richardson, M., Cappa, C. D., Law, D., and Murphy, D. M.: Aircraft instrumentation for comprehensive characterization of aerosol optical properties, Part 2: Black and brown carbon absorption and absorption enhancement measured with photo acoustic spectroscopy, Aerosol Sci. Tech., 46, 555568, 2012a.

Lack, D. A., Langridge, J. M., Bahreini, R., Brock, C. A., Middlebrook, A. M., and Schwarz, J. P.: Brown Carbon and Internal Mixing in Biomass Burning Particles, P. Natl. Acad. Sci., 109, 14802-14807, doi:10.1073/pnas.1206575109, 2012b.

Lanz, V. A., Alfarra, M. R., Baltensperger, U., Buchmann, B., Hueglin, C., Szidat, S. n., Wehrli, M. N., Wacker, L., Weimer, S., Caseiro, A., Puxbaum, H., and Prevot A. S.: Source Attribution of Submicron Organic Aerosols during Wintertime Inversions by Advanced Factor Analysis of Aerosol Mass Spectra, Environ. Sci. Technol., 42, 214-220, doi:10.1021/es0707207, 2007.

Lanz, V. A., Prévôt, A. S. H., Alfarra, M. R., Weimer, S., Mohr, C., DeCarlo, P. F., Gianini, M. F. D., Hueglin, C., Schneider, J., Favez, O., D'Anna, B., George, C., and Baltensperger, U.: Characterization of aerosol chemical composition with aerosol mass spectrometry in Central Europe: an overview, Atmos. Chem. Phys., 10, 10453-10471, doi:10.5194/acp-10-10453-2010, 2010.

Lewis, K., Arnott, W. P., Moosmuller, H., and Wold, C. E.: Strong spectral variation of biomass smoke light absorption and single scattering albedo observed with a novel dual-wavelength photoacoustic instrument, J. Geophys. Res., 113, D16203, doi:10.1029/2007jd009699, 2008.

Marley, N. A., Gaffney, J. S., Tackett, M., Sturchio, N. C., Heraty, L., Martinez, N., Hardy, K. D., Marchany-Rivera, A., Guilderson, T., MacMillan, A., and Steelman, K.: The impact of biogenic carbon sources on aerosol absorption in Mexico City, Atmos. Chem. Phys., 9, 1537-1549, doi:10.5194/acp-9-1537-2009, 2009.
Middlebrook, A. M., Bahreini, R., Jimenez, J. L., and Canagaratna, M. R.: Evaluation of Composition-Dependent Collection Efficiencies for the Aerodyne Aerosol Mass Spectrometer using Field Data, Aerosol Sci. Technol., 46, 258-271, doi:10.1080/02786826.2011.620041, 2011.

Moosmüller, H., Chakrabarty, R. K., Ehlers, K. M., and Arnott, W. P.: Absorption Ångström coefficient, brown carbon, and aerosols: basic concepts, bulk matter, and spherical particles, Atmos. Chem. Phys., 11, 1217-1225, doi:10.5194/acp-11-12172011, 2011.

Posfai, M., Simonics, R., Li, J., Hobbs, P. V., and Buseck, P. R.: Individual aerosol particles from biomass burning in southern Africa: 1. Compositions and size distributions of carbonaceous particles, J. Geophys. Res., 108, 8483, doi:10.1029/2002jd002291, 2003.

Posfai, M., Gelencser, A., Simonics, R., Arato, K., Li, J., Hobbs, P., and Buseck, P.: Atmospheric tar balls: Particles from biomass and biofuel burning, J. Geophys. Res., 109, D06213, doi:10.1029/2003jd004169, 2004.

Ramanathan, V. and Carmichael, G.: Global and Regional Climate Changes due to Black Carbon, Nature Geosci., 1, 221-227, 2008.

Reid, J. S., Koppmann, R., Eck, T. F., and Eleuterio, D. P.: A review of biomass burning emissions part II: intensive physical properties of biomass burning particles, Atmos. Chem. Phys., 5, 799825, doi:10.5194/acp-5-799-2005, 2005.

Roberts, J. M., Veres, P. R., Cochran, A. K., Warneke, C., Burling, I. R., Yokelson, R. J., Lerner, B., Gilman, J. B., Kuster, W. C., Fall, R., and de Gouw, J.: Isocyanic acid in the atmosphere and its possible link to smoke-related health effects, P. Natl. Acad. Sci. USA, 108, 8966-8971, doi:10.1073/pnas.1103352108, 2011.

Simoneit, B. R. T., Schauer, J. J., Nolte, C. G., Oros, D. R., Elias, V. O., Fraser, M. P., Rogge, W. F., and Cass, G. R.: Levoglucosan, a tracer for cellulose in biomass burning and atmospheric particles, Atmos. Environ., 33, 173-182, doi:10.1016/s13522310(98)00145-9, 1999.

Simpson, I. J., Akagi, S. K., Barletta, B., Blake, N. J., Choi, Y., Diskin, G. S., Fried, A., Fuelberg, H. E., Meinardi, S., Rowland, F. S., Vay, S. A., Weinheimer, A. J., Wennberg, P. O., Wiebring, P., Wisthaler, A., Yang, M., Yokelson, R. J., and Blake, D. R.: Boreal forest fire emissions in fresh Canadian smoke plumes: $\mathrm{C}_{1}-\mathrm{C}_{10}$ volatile organic compounds (VOCs), $\mathrm{CO}_{2}, \mathrm{CO}, \mathrm{NO}_{2}$, $\mathrm{NO}, \mathrm{HCN}$ and $\mathrm{CH}_{3} \mathrm{CN}$, Atmos. Chem. Phys., 11, 6445-6463, doi:10.5194/acp-11-6445-2011, 2011.

Smith, K. R.: Biofuels, Air Pollution, and Health: A Global Review (Modern Perspectives in Energy), 1st ed., Plenum Press, New York, 1987.

Stohl, A., Berg, T., Burkhart, J. F., Fjæraa, A. M., Forster, C., Herber, A., Hov, Ø., Lunder, C., McMillan, W. W., Oltmans, S., Shiobara, M., Simpson, D., Solberg, S., Stebel, K., Ström, J., Tørseth, K., Treffeisen, R., Virkkunen, K., and Yttri, K. E.: Arctic smoke - record high air pollution levels in the European Arctic due to agricultural fires in Eastern Europe in spring 2006, Atmos. Chem. Phys., 7, 511-534, doi:10.5194/acp-7-511-2007, 2007.

Ulbrich, I. M., Canagaratna, M. R., Zhang, Q., Worsnop, D. R., and Jimenez, J. L.: Interpretation of organic components from Positive Matrix Factorization of aerosol mass spectrometric data, Atmos. Chem. Phys., 9, 2891-2918, doi:10.5194/acp-9-2891-2009, 2009. 
Warneke, C., Froyd, K. D., Brioude, J., Bahreini, R., Brock, C. A., Cozic, J., de Gouw, J. A., Fahey, D. W., Ferrare, R., Holloway, J. S., Middlebrook, A. M., Miller, L., Montzka, S., Schwarz, J. P., Sodemann, H., Spackman, J. R., and Stohl, A.: An important contribution to springtime Arctic aerosol from biomass burning in Russia, Geophys. Res. Lett., 37, L01801, doi:10.1029/2009g1041816, 2010.

Williams, E., Lerner, B., Murphy, P., Herndon, S. C., and Zahniser, M. S.: Emissions of $\mathrm{NO}_{\mathrm{x}}, \mathrm{SO}_{2}, \mathrm{CO}$, and $\mathrm{C}_{2} \mathrm{H}_{4}$ from Commercial Marine Shipping During Texas Air Quality Study (TexAQS) 2006, J. Geophys. Res., 114, D21306, doi:10.1029/2009JD012094, 2009.
Yang, M., Howell, S. G., Zhuang, J., and Huebert, B. J.: Attribution of aerosol light absorption to black carbon, brown carbon, and dust in China - interpretations of atmospheric measurements during EAST-AIRE, Atmos. Chem. Phys., 9, 2035-2050, doi:10.5194/acp-9-2035-2009, 2009. 